\title{
The Development of Ski Areas in Romania. What Environmental, Political, and Economic Logic?
}

\author{
Sorina Cernaianu ${ }^{1,2,3, *}$ and Claude Sobry ${ }^{2,3}$ \\ 1 Faculty of Physical Education and Sport, University of Craiova, 200207 Craiova, Romania \\ 2 ULR 7369-URePSSS-Unité de Recherche Pluridisciplinaire Sport Santé Société, University of Lille, \\ F-59000 Lille, France; claude.sobry@univ-lille.fr \\ 3 International Research Network in Sport Tourism, F-59000 Lille, France \\ * Correspondence: sorina.cernaianu@edu.ucv.ro
}

check for updates

Citation: Cernaianu, S.; Sobry, C. The Development of Ski Areas in Romania. What Environmental, Political, and Economic

Logic? Sustainability 2021, 13, 274. https://doi.org/10.3390/su13010274

Received: 15 November 2020 Accepted: 24 December 2020 Published: 30 December 2020

Publisher's Note: MDPI stays neutral with regard to jurisdictional clai$\mathrm{ms}$ in published maps and institutional affiliations.

Copyright: (C) 2020 by the authors. Licensee MDPI, Basel, Switzerland. This article is an open access article distributed under the terms and conditions of the Creative Commons Attribution (CC BY) license (https:// creativecommons.org/licenses/by/ $4.0 /)$.

\begin{abstract}
In the last years, Romania has made major efforts to develop the skiing areas and some important projects have been implemented in the Carpathian Mountains. This research highlights the low efficiency of ski slopes and ski areas concerning the functionality during the winter season, even though a number of investments have been made. Some examples of bad practices regarding the development of skiing infrastructure in link with the potential impact on the environment are presented. The status of ski slopes, slope conditions, and snow depth were collected daily, during the 2016-2017 and 2017-2018 winter seasons, from a Romanian website specialized in snow cover information. A statistical analysis based on the collected data has been done. The 225 ski slopes studied have been opened, on average, less than 62 days and more than $20 \%$ of them have not even been opened. Only $17.8 \%$ of the slopes complied with the "100-day rule" during the first season and $21.3 \%$ of them during the second one, which does not ensure profitability. In conclusion, too many ski slopes have been created without considering the actual snow conditions. The investors wasted capital that is unprofitable and needlessly, affecting the environmental sustainability.
\end{abstract}

Keywords: winter sport tourism; ski slopes; ski areas; sustainability; investment; public policies; development impacts; climate change; Romania

\section{Introduction}

Snow, the white gold, and all the sports that are associated with it, have allowed to develop a real tourism industry, first in Western Europe and North America, today in Central and Eastern Europe and in China. If, at the beginning, everything was sacrificed to develop and create ski resorts, nature and landscape, local populations, for economic efficiency, times have changed and sustainable development becomes the ultimate goal. Or, should we say, "should be the ultimate goal".

Times have changed in another way, too: Global warming with weather disturbances, retreating or disappearing glaciers, and snow that only falls at high altitudes. Everywhere in Europe, low-altitude ski resorts, less than $1200 \mathrm{~m}$, sometimes up to $500 \mathrm{~m}$ above sea level, go bankrupt and disappear or are in great difficulty if there are not massive investments to ensure the diversification of the activities offered to tourists.

In this context, the position of public and private decision-makers is not simple, separated by the desire to develop a potential resource — and job-creating activity—and the new environmental constraints. These constraints are no longer only of a conceptual nature, but are included in the programs of the major international bodies.

In 2014, an agreement between the United Nations and the International Olympic Committee (IOC) underlined that the two bodies "share the same values of contributing to a better and peaceful world through sport" [1], in substance, meaning that the IOC integrate the UN 17 Sustainable Development Goals [2]. 
How do Romanian decision-makers consider these different elements in their policy of developing winter sports, especially skiing? Are investments both economically and environmentally sound?

Situated in the heart of Europe, Romania is a country with an important tourism potential. If we speak about winter sports, the Carpathian Mountains represent the right place to practice skiing in this country. In general, high altitudes guarantee a long functionality of a ski slope during the winter. The relief is not so "generous" in this country from this point of view because $90 \%$ of mountain area is less than $1500 \mathrm{~m} \mathrm{[3].} \mathrm{The} \mathrm{highest} \mathrm{peak} \mathrm{in} \mathrm{the}$ country is Moldoveanu (2544 m) and there are 22 peaks higher than $2000 \mathrm{~m}$.

Before the Revolution of 1989, which marked the end of the communist period, the development of ski areas in Romania has not been the main focus of attention. Nor in the next years, during the post-communist transition, has the state of winter tourism improved considerably. The old infrastructure, the non-competitive prices compared to other countries like Bulgaria and Austria, and the poor quality of tourist services led to the loss of winter sports market [4].

Since the 2000s, when the Romanian economy experienced revitalization, a series of studies and projects have been made in order to see if a new ski infrastructure and the modernization of the existing one would be beneficial for the country. These actions have represented the premises for several future national projects [5].

An analysis of the natural tourist potential of the country focused especially on skiing led to the necessity of a project for modernization and extension of the ski areas, ski lifts, and other types of facilities for winter sports [6]. Thus, the Romanian Parliament adopted the Law No 526/2003 of 16 December 2003, approving “The National Program for the development of mountain tourism "Super-ski in the Carpathians" " with the main component "tourism for skiing and other winter sports". According to Article 3 of this law, an integrated study was carried out by the Ministry of Transport, Construction, and Tourism, through the National Institute for Research and Development in Tourism, in collaboration with companies of design and consulting in the field. Three stages have been provided for the implementation of this program: The first one covered the resorts situated in the Prahova Valley area, which is the most representative region of winter sports in Romania, with an existing infrastructure and several tourism development projects in various phases of development; the second one included some resorts and tourist localities other than in the Prahova Valley; and the third one comprised new resorts or tourist centers in new locations, situated close to localities or in areas supported by only one chalet [7]. The areas where winter sports can be practiced (especially skiing) have been identified, and a diagnostic analysis of each one has been done. The partnership between central and local public administration on the one hand, and the private sector, on the other, contributes to the development of these areas.

A series of changes and regulations occurred in 2004, 2006, 2008, 2009, 2013, and 2019. In 2006, the title of the former law was changed, and it became "Ski in Romania". If at the beginning, three types of resorts were considered, some of them with a background concerning the practice of winter sports, the new changes took into consideration the implementation of an integrated study in order to identify new areas [8].

Even if it was not a perfect legislation from the beginning, these laws represented the premises for the development of the ski infrastructure in Romania, the political part playing a key role in making decisions and implementing development projects. However, these investments were made differently, depending on the following classification of tourist resorts: Of national interest (51 resorts) and of local interest (75 resorts) [9]. Of these resorts, more than a half is situated in the Carpathian area. According to the article 12 of Government Decision No 122/2002 "the tourist resorts of national interest are included with priority in the annual tourist promotion programs, in the development of tourist products and in the development of the general infrastructure" [10]. It should also be mentioned that the priority for the investment programs financed by the state budget and by European funds. In other words, the developed tourist resorts were preferred for 
investments. Nevertheless, the small localities that could not support themselves from agriculture applied for European projects, in order to make them more attractive to tourists.

In 2016, Romania had 183 certified ski slopes, with a total length of $161 \mathrm{~km} \mathrm{[11].}$ Taking into account the non-certified slopes as well, Romania counted 266 ski slopes $(256.7 \mathrm{~km})$ grouped in $92 \mathrm{ski}$ areas, of which 112 slopes are easy and very easy $(42.1 \%$ $89.5 \mathrm{~km}), 114$ slopes have a medium level $(42.9 \%-116.6 \mathrm{~km})$, and 40 slopes are difficult $(15 \%-50.6 \mathrm{~km})$ [12]. In 2019, the number of certified slopes increased to 195, with a total length of $169 \mathrm{~km}[13]$.

\section{Ski Slopes and Environment in Romania}

Signatory of the Framework Convention on the Protection and Sustainable Development of the Carpathians adopted in Kiev on 22 May 2003, together with six other countries (Czech Republic, Hungary, Poland, Slovak Republic, Serbia, and Ukraine), Romania engaged to improve the quality of life, to strengthen the local economies and communities, and to conserve the natural values and cultural heritage [14], three elements very close to the "three pillars" of sustainability as defined by the Brundtland report [15].

Regarding sustainable tourism, we focused on the article 9(1) and (2) of this convention, which mentions that "The Parties shall take measures to promote sustainable tourism in the Carpathians, providing benefits to the local people, based on the exceptional nature, landscapes and cultural heritage of the Carpathians...". To detail this general provision, we took into consideration The Protocol on Sustainable Tourism to the convention that have been adopted and signed by the parts during the third ordinary meeting, which was held in Bratislava on 25-27 May 2011 [16]. The article 1(3) of this protocol regulates specific substantive obligations.

Alberton et al. [17] underlined that this convention, coordinator of supranational policies, gives three precise and important recommendations in the field of tourism:

- To take into consideration the climate change for future tourism strategies and investments;

- To diversify the tourism in order to not be dependent on snow cover;

- $\quad$ To avoid using energy-intensive snow cannons.

Are these recommendations followed by effects? It is not so clear.

Investments in ski resorts must take into account the climate changes. This variable is underlined by all the authors having studied either the meteorology or the development conditions of ski resorts, not only in Europe but in the world as a whole. Scott, Steiger, Rutty, and Johnson [18] cited by Goldblatt [19] highlighted, among others, that 11 of 19 previous Winter Olympic cities will be reliable hosts of winter sports in the 2050s and only six in the 2080s. In the traditional ski countries, France, Austria, and Switzerland mostly, ski resorts are closing, or other leisure activities are proposed (snowshoeing, hiking, mountain biking, etc.), and investments are focused on structures such as swimming pools, spas, etc. These resorts are transformed to achieve a functioning called "of the four seasons". This conversion began during the 1990s, after a three to four-year period of very low snow cover in the late 1980s.

Ski slopes built at low altitudes need artificial snow to be operable as long as possible. The production of this snow involves a high consumption of energy and water, affects the fauna, flora, and soil, and pollutes due to substances introduced into the water [20].

Due to the increasing temperatures during the winter season, the quality of the snow cover is poor, and its existence is uncertain. Even artificial snow cover poses problems. To produce artificial snow, the temperature should fall under $1^{\circ} \mathrm{C}$ without the addition of chemicals. As a consequence, only the ski slopes situated at higher altitude or north facing will be operable [16]. Beninston [21] in his study regarding the snow variability in the Swiss Alps argued that "large-scale forcing, and not local or regional factors, plays a dominant role in controlling the timing and amount of snow". The research conducted by Bojariu and Dinu [22] concluded another way stating that, in Romanian mountain regions, this is exactly the opposite: Predominant in snow-pack variability are the local and regional 
factors. A study carried out by Micu [23] regarding snow pack in the Romanian Carpathians showed that in terms of temperature "the 1990s marked indeed the beginning of a more evident warming process at most of the Romanian Carpathian sites, without being closely related to less frequent snowfalls ..." . The same study revealed that "warmer extreme winter temperatures tended to rise especially at medium and low altitudes" and the snowpack duration is shorter at altitudes lower than 1600-1700 m. The author of this study predicted wetter and less snowy weather in the Romanian Carpathian Mountains for the next years.

As a result of a study concerning the impact of reducing the snow cover on the skiing conditions, the Romanian National Meteorological Administration noted in its 2016 report that "The number of days with good snow conditions for skiing during a season is decreasing in the Carpathians, in the context of climate change" [24].

Teodor [12] pointed out that, in order for a ski area to be functional, several relief and environmental factors must be considered, among which we mention: Natural factors-ideal slopes, northern, north-western, and north-eastern exposure of the relief, high altitude, level difference, as large as possible (correlated with the length of the slope and its degree of difficulty), accessibility to the ski area; climatic factors - temperature, snow depth, wind; anthropic factors - transport infrastructure (ski areas accessible to tourists), tourist infrastructure (ski lifts, accommodation, food, etc.); economic factors (ski equipment, ski pass, etc.).

Witmer, Filliger, Kunz, and Kung [25], cited by Abegg, Agrawala, Crick, and Montfalcon [26] and Marty [27], referring to the functionality of a ski slope, considered that "a snow depth of $30 \mathrm{~cm}$ is considered sufficient, $50 \mathrm{~cm}$ good, and $70 \mathrm{~cm}$ excellent". In addition, Witmer et al. [25], cited by Yang and Wan [28], stated that only ski areas that are operable at least 100 days per season would be financially viable (so called "100-day rule").

The development of any ski resort causes a series of damages, primarily on vegetation, soil, and landscape [29,30]. Deforestation, stripping of vegetation, or, sometimes, improper execution of a ski slope can lead to important damages, with adverse consequences for the environment. Concerning the landscape, we cannot forget the view of the pylons and cables, most often useless during summer but always clearly visible, the use of construction site machinery that compacts or tears up fragile soils, and the noise they make, as well as helicopters used to move loads, scaring wildlife.

Structural errors or failure to comply with environmental conditions can lead to real disasters. Cocos slope (1335 m long), an investment of 4.4 million euro of the municipality, built near the city of Bistrita, at a starting altitude of only $676 \mathrm{~m}$, an arrival altitude of $457 \mathrm{~m}$, and equipped with a chairlift and four snow cannons, is the most eloquent example. Although the construction was finished since February 2017, the slope was opened to the public after a year because of unfavorable weather conditions. A few months after the opening of the ski slope, the municipality announced that funding is needed for repairs "because of a landslide upstream of the designated accumulation lake for snow production" [31]. How efficient can be this investment paid from public money for the inhabitants of this city and not only? The slope was functional only 10 days in 2018 (January-three days, February - two days, and March-five days), and 14 days in 2019. Concerning the economic impact, a study by Bica, Schuster, and Stefanescu [32] showed that during the 2017-2018 winter season the maintenance costs were nine times higher than the revenues.

The lack of financial resources led to get stall of some ski projects or not be completed on time. An example is the Rarau ski slope with a length of $2850 \mathrm{~m}$, a gondola lift, and nine snow cannons, inaugurated in 2019 after 10 years from the beginning of the works and in which 15 million euro were invested with a contribution of $90 \%$ of public funds [33].

The ski slope from Horea village was part of a project included in national program "Ski in Romania". It started in 2010 and involved the construction of an 850 m ski slope, equipped with snow cannons and ski lift. For the technical project and deforestation (30 ha of forest) more than 300,000 euro were spent, but the project was abandoned in 2012 because of the lack of money. Another 2 million euro would be needed to complete 
it [34]. However, when will this project be resumed, and if not, how many years are necessary for reforestation?

Copou ski slope near Iasi (the 4th largest city in Romania) was opened in 2014, with a length of only $420 \mathrm{~m}$ (departure altitude at $370 \mathrm{~m}$ and arrival altitude at $320 \mathrm{~m}$ ). This slope is equipped with a ski lift and nightlight, its functionality depending on the climatic conditions favorable for skiing a very short period of time. However, even when it is functional, the slope has a series of problems such as technical breakdowns of the ski lift, which is old and unprofitable (the investment was not amortized until today) or the insufficiency of ski equipment for rent (only 20 equipment available) [35]. However, there is a solution for those who want to ski: In Iasi, the first indoor ski simulator in Romania has been opened, equipment used by snowboarders, too.

This list of examples could go on.

\section{The Purpose of the Study}

Vanat [36], in his yearly international report on snow and mountain tourism referring to winter season 2017-2018, stated that in Romania, "snow conditions can be very good through the end of March or even April". This assertion is general and would require some refinements depending on the exposure, the runway, the altitude, and the region concerned.

Many important projects have been implemented in the Carpathian Mountains during the last years in order to develop the skiing infrastructure. Some of them considered the modernization of the existing ski resorts while others developed new ones. Two questions arise: What consequences do they have on the environment, mostly on the landscape, and which of them may appear as a real success or a failure, at the economic, sociologic, and environmental level? Taking into consideration the characteristics of Romanian mountain area and skiing infrastructure, this research aims to highlight the low efficiency of ski slopes and ski areas concerning the functionality during the winter season, despite the fact that a number of investments has been made, either from public money, sponsorships, or European funds. At the same time, this research would like to present some examples of bad practices regarding the development of skiing infrastructure in link with the potential impact on the environment.

Therefore, we hypothesized that:

1. Investments aimed at the development of ski slopes do not take into account climate change and the slopes can be functional only a few days per season or not at all.

2. Investors, private and public, fail to comply with international commitments regarding the use of snow cannons and other artificial means to maintain ski activity.

\section{Materials and Methods}

The research was carried out during the 2017-2018 winter season, from 29 November 2017 to 15 April 2018, with a total of 138 days. For certain analyses, we used also the data collected during the previous season (2016-2017), which were divided into two periods: From 19 November to 17 April, and from 21 April to 27 April, with three days break because of the lack of snow. This season lasted 157 days (see Table 1):

For this research we took into account 225 ski slopes from 69 ski areas of Romanian Carpathians Mountains, representing more than $80 \%$ of the total number of existing ski slopes in the country. The ski runs technically closed have not been included in the study.

The research design has been structured into two stages.

The first stage was focused on the ski slopes characteristics, starting altitude, and arrival altitude, collected from "Romania turistica" website, specialized in snow cover information [37]. Furthermore, the presence or absence of snow cannons has been taken into consideration. 
Table 1. The period and the number of days the ski slopes were functional during the two consecutive winter seasons (2016-2017 and 2017-2018).

\begin{tabular}{cccccc}
\hline $\begin{array}{c}\text { 2016-2017 } \\
\text { Month }\end{array}$ & Period of Time & Number of Days & $\begin{array}{c}\text { 2017-2018 } \\
\text { Month }\end{array}$ & Period of Time & Number of Days \\
\hline November 2016 & 19th-30th & 12 & November 2017 & 29th-30th & 2 \\
December 2016 & 1st-31th & 31 & December 2017 & 1st-31th \\
January 2017 & 1st-31th & 31 & January 2018 & 1st-31th \\
February 2017 & 1st-28th & 28 & February 2018 & 1st-28th \\
March 2017 & 1st-31th & 31 & March 2018 & 1st-31th \\
April 2017 & 1st-17th and 21st-27th & 24 & April 2018 & 1st-15th \\
Total & 19th November-27th & 157 & Total & 29th November-15th \\
& April & \multicolumn{4}{c}{ April } \\
\hline
\end{tabular}

In the second stage the status of the ski slopes, slope conditions and snow depth were collected daily, during the 157 days of the 2016-2017 winter season and 138 days of the 2017-2018, from the same website, for each functional ski slope included in the study. Each day was archived in a Word document, as text or snipped images, and then recorded in an SPSS file.

The variable status of the ski slopes was presented on the website with three categories: Open, open-impracticable, and closed. The open-impracticable slopes had some damaged areas because the quality of the snow was affected by warming weather. Consequently, for some statistics calculations, these ski slopes have been considered together with the closed ones. The average for each category of this variable has been calculated, by month, as well as the maximum and minimum percentage values.

The variable slope conditions reported on the website has three categories-closed, impracticable, and wind - relating to non-operable ski slopes, and another six for open ski slopes: Open, difficult conditions, acceptable conditions, good conditions, very good conditions, and excellent conditions placed on a scale progressively from bad to excellent. This scale is designed for the purpose of assessing the ease to ski on the slope, and the data are reported for the ski industry. The assessment is made by evaluators, based on several objective elements such as the snowfall from the past $24 \mathrm{~h}$, its consistency, the slope grooming, etc., and could be a little bit different from a resort to another. This kind of scale is used in other countries, too, with more or less categories.

Closed, impracticable, and wind were considered together for some statistics calculations. The average, maximum, and minimum values, by month, have been calculated for each category.

The snow depth has been registered from the website only for the open ski slopes. Additionally, we calculated the average, the maximum, and the minimum of days that the snow depth had the highest value during the season.

Two parameters regarding the length of the ski season for a ski area have been considered:

1. The number of days that at least one ski slope was open in a ski area;

2. The number of days that a ski area has been operated at maximum capacity (all ski slopes of this ski area were open).

We created the first dataset, containing the following variables (see Table 2):

On the basis of the collected data, we performed a univariate and bivariate statistical analysis using SPSS Statistics 22.0 software. 
Table 2. The variables included in the study for the second stage of the research.

\begin{tabular}{ccc}
\hline Variables & Open Slopes & $\begin{array}{c}\text { Closed and } \\
\text { Open-Impracticable } \\
\text { Slopes }\end{array}$ \\
\hline 1. Date & $\mathrm{x}$ & $\mathrm{x}$ \\
2. Name of the ski area & $\mathrm{x}$ & $\mathrm{x}$ \\
3. Name of the ski slope & $\mathrm{x}$ & $\mathrm{x}$ \\
4. Status of the ski slopes & $\mathrm{x}$ & - \\
5. Snow depth & $\mathrm{x}$ & - \\
6. Ski slope conditions & $\mathrm{x}$ & $35,325(157$ days $\times 225$ ski slopes $)$ \\
\hline Total number of records (2016-2017) & $31,050(138$ days $\times 225$ ski slopes $)$ \\
\hline Total number of records (2017-2018) & \multicolumn{2}{c}{66,375 records } \\
\hline Total
\end{tabular}

\section{Results and Discussion}

\subsection{First Stage}

\subsubsection{Starting Altitude and Arrival Altitude}

Analyzing the data concerning starting altitude, we observe that $19.11 \%$ of slopes are situated at less than $1000 \mathrm{~m}, 35.55 \%$ at less than $1200 \mathrm{~m}$, and $66.22 \%$ at less than $1500 \mathrm{~m}$. The arrival altitude is less than $1000 \mathrm{~m}$ for $35.56 \%$ of ski slopes, while almost $80 \%$ are less than $1500 \mathrm{~m}$. The ski slopes situated entirely at least $1500 \mathrm{~m}$ high represent $20.44 \%$ of the total, in fact, a small percentage, considering the impact of climate change on their functionality (see Table 3).

Table 3. Contingency table: Starting altitude and arrival altitude of the 225 ski slopes.

\begin{tabular}{|c|c|c|c|c|c|c|}
\hline \multirow{2}{*}{ Starting Altitude (m) } & & \multicolumn{4}{|c|}{ Arrival Altitude (m) } & \multirow{2}{*}{ Total Slopes } \\
\hline & & $<1000$ & $1000-1199$ & 1200-1499 & 1500-1999 & \\
\hline \multirow[t]{2}{*}{$<1000$} & Count & 43.00 & 0.00 & 0.00 & 0.00 & 43.00 \\
\hline & $\%$ of Total & 19.11 & 0.00 & 0.00 & 0.00 & 19.11 \\
\hline \multirow[t]{2}{*}{$1000-1199$} & Count & 21.00 & 16.00 & 0.00 & 0.00 & 37.00 \\
\hline & $\%$ of Total & 9.33 & 7.11 & 0.00 & 0.00 & 16.44 \\
\hline \multirow[t]{2}{*}{ 1200-1499 } & Count & 13.00 & 27.00 & 29.00 & 0.00 & 69.00 \\
\hline & $\%$ of Total & 5.78 & 12.00 & 12.89 & 0.00 & 30.67 \\
\hline \multirow[t]{2}{*}{ 1500-1999 } & Count & 3.00 & 7.00 & 20.00 & 33.00 & 63.00 \\
\hline & $\%$ of Total & 1.33 & 3.11 & 8.89 & 14.67 & 28.00 \\
\hline \multirow[t]{2}{*}{$\geq 2000$} & Count & 0.00 & 0.00 & 0.00 & 13.00 & 13.00 \\
\hline & $\%$ of Total & 0.00 & 0.00 & 0.00 & 5.78 & 5.78 \\
\hline \multirow[t]{2}{*}{ Total slopes } & Count & 80.00 & 50.00 & 49.00 & 46.00 & 225.00 \\
\hline & $\%$ of Total & 35.56 & 22.22 & 21.78 & 20.44 & 100.00 \\
\hline
\end{tabular}

If we refer only to the 175 functional ski slopes during the 2017-2018 winter season, the departure is situated at less than $1000 \mathrm{~m}$ for $16 \%$ of slopes, less than $1200 \mathrm{~m}$ for $30.86 \%$, and less than $1500 \mathrm{~m}$ for $63.43 \%$ of them. The percentages of the arrival altitude are similar to those calculated for the entire sample: $32 \%$ of slopes less than $1000 \mathrm{~m}, 55.43 \%$ of them less than $1200 \mathrm{~m}$, and $77.72 \%$ of ski slopes less than $1500 \mathrm{~m}$ (see Table 4). 
Table 4. Contingency table: Starting altitude and arrival altitude of the 175 functional ski slopes during the 2017-2018 winter season.

\begin{tabular}{|c|c|c|c|c|c|c|}
\hline \multirow{2}{*}{ Starting Altitude (m) } & & \multicolumn{4}{|c|}{ Arrival Altitude (m) } & \multirow{2}{*}{ Total Slopes } \\
\hline & & $<1000$ & 1000-1199 & 1200-1499 & 1500-1999 & \\
\hline \multirow[t]{2}{*}{$<1000$} & Count & 28.00 & 0.00 & 0.00 & 0.00 & 28.00 \\
\hline & $\%$ of Total & 16.00 & 0.00 & 0.00 & 0.00 & 16.00 \\
\hline \multirow[t]{2}{*}{ 1000-1199 } & Count & 15.00 & 11.00 & 0.00 & 0.00 & 26.00 \\
\hline & $\%$ of Total & 8.57 & 6.29 & 0.00 & 0.00 & 14.86 \\
\hline \multirow[t]{2}{*}{$1200-1499$} & Count & 10.00 & 23.00 & 24.00 & 0.00 & 57.00 \\
\hline & $\%$ of Total & 5.71 & 13.14 & 13.71 & 0.00 & 32.57 \\
\hline \multirow[t]{2}{*}{ 1500-1999 } & Count & 3.00 & 7.00 & 15.00 & 27.00 & 52.00 \\
\hline & $\%$ of Total & 1.71 & 4.00 & 8.57 & 15.43 & 29.71 \\
\hline \multirow[t]{2}{*}{$\geq 2000$} & Count & 0.00 & 0.00 & 0.00 & 12.00 & 12.00 \\
\hline & $\%$ of Total & 0.00 & 0.00 & 0.00 & 6.86 & 6.86 \\
\hline \multirow[t]{2}{*}{ Total slopes } & Count & 56.00 & 41.00 & 39.00 & 39.00 & 175.00 \\
\hline & $\%$ of Total & 32.00 & 23.43 & 22.29 & 22.29 & 100.00 \\
\hline
\end{tabular}

\subsubsection{Snow Cannons}

About a half of the ski slopes were equipped with snow cannons (48.89\%). If we count only the functional slopes, snow cannons were present on $56.67 \%$ of them. More important is to know at what altitude are situated the slopes who benefit from this facility. Therefore, we analyzed this variable crossing with starting and arrival altitudes. The values of these variables have been grouped by class intervals.

At a first analysis of the data, the ski slopes with departure at least $2000 \mathrm{~m}$ altitude were not equipped with snow cannons. The highest proportion was registered for the slopes situated at less than $1000 \mathrm{~m}$ (67.44\% of them, calculated for all the ski slopes and 85.71\% of them, if we take into consideration only the functional slopes during the 2017-2018 winter season) (see Table 5).

Table 5. Contingency table: Snow cannons and starting altitude.

\begin{tabular}{|c|c|c|c|c|c|c|c|}
\hline \multirow{3}{*}{$\begin{array}{c}\begin{array}{c}\text { Starting } \\
\text { Altitude }\end{array} \\
(\mathrm{m})\end{array}$} & & \multicolumn{3}{|c|}{ All Ski Slopes (225) } & \multicolumn{3}{|c|}{ Functional Ski Slopes (175) } \\
\hline & & \multicolumn{3}{|c|}{ Snow Cannons } & \multicolumn{3}{|c|}{ Snow Cannons } \\
\hline & & Yes & No & Total & Yes & No & Total \\
\hline \multirow[t]{2}{*}{$<1000$} & Count & 29.00 & 14.00 & 43 & 24.00 & 4.00 & 28 \\
\hline & $\%$ within SA * & 67.44 & 32.56 & 100 & 85.71 & 14.29 & 100 \\
\hline \multirow[t]{2}{*}{ 1000-1199 } & Count & 17.00 & 20.00 & 37 & 15.00 & 11.00 & 26 \\
\hline & $\%$ within SA & 45.95 & 54.05 & 100 & 57.69 & 42.31 & 100 \\
\hline \multirow[t]{2}{*}{ 1200-1499 } & Count & 38.00 & 31.00 & 69 & 35.00 & 22.00 & 57 \\
\hline & $\%$ within SA & 55.07 & 44.93 & 100 & 61.40 & 38.60 & 100 \\
\hline \multirow[t]{2}{*}{ 1500-1999 } & Count & 26.00 & 37.00 & 63 & 25.00 & 27.00 & 52 \\
\hline & \% within SA & 41.27 & 58.73 & 100 & 48.08 & 51.92 & 100 \\
\hline \multirow[t]{2}{*}{$\geq 2000$} & Count & 0.00 & 13.00 & 13 & 0.00 & 12.00 & 12 \\
\hline & \% within SA & 0.00 & 100.00 & 100 & 0.00 & 100.00 & 100 \\
\hline \multirow[t]{2}{*}{ Total } & Count & 110.00 & 115.00 & 225 & 99.00 & 76.00 & 175 \\
\hline & $\%$ within SA & 48.89 & 51.11 & 100 & 56.67 & 43.43 & 100 \\
\hline
\end{tabular}


In order to extend the functionality period of the slopes, investments were made in snow cannons even on the slopes located at least $1500 \mathrm{~m}$ altitude $(48.08 \%$ of them being equipped).

Concerning the cross-classification table between the snow cannons and arrival altitude we observe that there are ski slopes equipped with snow cannons in all the four class intervals. As the arrival altitude increases, the percentage of snow cannons presence decreases. The highest proportion of slopes with snow cannons was registered at an arrival altitude less than $1000 \mathrm{~m}$ (61.25\% of them, calculated for all the ski slopes and $73.21 \%$ of them, calculated for the functional slopes during the 2017-2018 winter season) (see Table 6).

Table 6. Contingency table: Snow cannons and arrival altitude.

\begin{tabular}{|c|c|c|c|c|c|c|c|}
\hline \multirow{2}{*}{$\begin{array}{c}\text { Arrival } \\
\text { Altitude }\end{array}$} & & \multicolumn{3}{|c|}{ All Ski Slopes (225) } & \multicolumn{3}{|c|}{ Functional Ski Slopes (175) } \\
\hline & & \multicolumn{3}{|c|}{ Snow Cannons } & \multicolumn{3}{|c|}{ Snow Cannons } \\
\hline (m) & & Yes & No & Total & Yes & No & Total \\
\hline \multirow[t]{2}{*}{$<1000$} & Count & 49.00 & 31.00 & 80 & 41.00 & 15.00 & 56 \\
\hline & $\%$ within $\mathrm{AA}$ * & 61.25 & 38.75 & 100 & 73.21 & 26.79 & 100 \\
\hline \multirow[t]{2}{*}{ 1000-1199 } & Count & 25.00 & 25.00 & 50 & 23.00 & 18.00 & 41 \\
\hline & $\%$ within AA & 50.00 & 50.00 & 100 & 56.10 & 43.90 & 100 \\
\hline \multirow[t]{2}{*}{ 1200-1499 } & Count & 24.00 & 25.00 & 49 & 23.00 & 16.00 & 39 \\
\hline & $\%$ within AA & 48.98 & 51.02 & 100 & 58.97 & 41.03 & 100 \\
\hline \multirow[t]{2}{*}{ 1500-1999 } & Count & 12.00 & 34.00 & 46 & 12.00 & 27.00 & 39 \\
\hline & $\%$ within AA & 26.09 & 73.91 & 100 & 30.77 & 69.23 & 100 \\
\hline \multirow[t]{2}{*}{ Total } & Count & 110.00 & 115.00 & 225 & 99.00 & 76.00 & 175 \\
\hline & $\%$ within AA & 48.89 & 51.11 & 100 & 56.67 & 43.43 & 100 \\
\hline
\end{tabular}

The Romanian ski slopes were equipped with snow-making facilities not only at low altitudes, due to climate change affecting the snow cover duration and, implicitly, the length of the ski season.

\subsection{Second Stage}

4.2.1. Efficiency of the Ski Slopes: The Status of the Ski Slopes

The winter season 2017-2018 started at the end of November 2017, with an average of $5.11 \%$ open ski slopes (compared to $1.04 \%$ in the previous season) and a maximum of $7.11 \%$ (3.11\% in 2016-2017 season). In December, there were no remarkable values in terms of ski slopes status, on average about $24 \%$ of them being operable ( $26.11 \%$ one year before), with a maximum of $46.22 \%$ open slopes compared to $47.11 \%$ a season earlier. In fact, we are witnessing a staggered season, the highest average being registered in February $(68.9 \%)$, even if the maximum of open ski slopes was reached in March. The previous season recorded a maximum of $67.11 \%$ in January and February, and the highest average in February (63.83\%). In average, the number of open ski slopes throughout the season was $44.33 \%$, compared to $35.96 \%$ in $2016-2017$. Furthermore, it should be noted the high average percentage of closed and impracticable ski slopes in December 2017 (76.03\%) as well during all the winter season (64.04\% in 2016-2017 and 55.7\% in 2017-2018) (see Table 7, see Table 8).

The season 2016-2017 began in November with a small percentage of open slopes, which is normal for this period. As shown in Figure 1, in December, we observed increases and plateaus, reaching a maximum of $47.11 \%$ open slopes in the last day. Only on 5 January was the percentage of open slopes $(50.67 \%)$ higher than those of closed and openimpracticable, with a maximum between 29 January and 2 February (67.11\%). 9 March was the day when the percentage of functional slopes decreased below $50 \%$. The curve 
continued to decline until 17 April. The lack of snow led to the closure of the ski slopes for three days $(18,19,20$ April). Starting with 21 April, less than $10 \%$ of the slopes were reopened for another seven days and the ski season closed on 27 April (see Figure 1).

Table 7. The ski slope status-average, maximum and minimum values, by month, during the 2016-2017 winter season.

\begin{tabular}{|c|c|c|c|c|c|c|c|c|}
\hline Status & $\begin{array}{l}\text { Month } \\
\text { Index }\end{array}$ & $\begin{array}{l}\text { November } \\
2016\end{array}$ & $\begin{array}{c}\text { December } \\
2016\end{array}$ & $\begin{array}{c}\text { January } \\
2017\end{array}$ & $\begin{array}{c}\text { February } \\
2017\end{array}$ & $\begin{array}{c}\text { March } \\
2017\end{array}$ & $\begin{array}{c}\text { April } \\
2017\end{array}$ & $\begin{array}{l}\text { Total } \\
\text { Season }\end{array}$ \\
\hline \multirow{3}{*}{$\begin{array}{c}\text { Open } \\
(\%)\end{array}$} & $A v^{1}$ & 1.04 & 26.11 & 60.16 & 63.83 & 35.00 & 3.63 & 35.96 \\
\hline & $\operatorname{Max}^{2}$ & 3.11 & 47.11 & 67.11 & 67.11 & 62.22 & 9.33 & 67.11 \\
\hline & $\operatorname{Min}^{3}$ & 0.44 & 3.56 & 47.11 & 61.78 & 6.67 & 1.78 & 0.44 \\
\hline \multirow{3}{*}{$\begin{array}{c}\text { Open- } \\
\text { Impracticable } \\
(\%)\end{array}$} & $\mathrm{Av}$ & 0.00 & 1.84 & 1.95 & 4.89 & 11.44 & 0.15 & 3.90 \\
\hline & Max & 0.00 & 3.56 & 7.11 & 7.11 & 16.89 & 3.56 & 16.89 \\
\hline & Min & 0.00 & 0.00 & 1.33 & 1.78 & 3.56 & 0.00 & 0.00 \\
\hline \multirow{3}{*}{$\begin{array}{c}\text { Closed } \\
(\%)\end{array}$} & $\mathrm{Av}$ & 98.96 & 72.06 & 37.89 & 31.29 & 53.56 & 96.22 & 60.14 \\
\hline & Max & 99.56 & 96.44 & 32.44 & 32.44 & 89.78 & 98.22 & 99.56 \\
\hline & Min & 96.89 & 49.33 & 31.11 & 29.78 & 31.11 & 89.78 & 29.78 \\
\hline \multirow{3}{*}{$\begin{array}{c}\text { Closed + } \\
\text { Open- } \\
\text { Impracticable }\end{array}$} & $\mathrm{Av}$ & 98.96 & 73.89 & 39.84 & 36.17 & 65.00 & 96.37 & 64.04 \\
\hline & Max & 99.56 & 96.44 & 38.22 & 38.22 & 93.33 & 98.22 & 99.56 \\
\hline & Min & 96.89 & 49.33 & 31.11 & 29.78 & 31.11 & 89.78 & 29.78 \\
\hline
\end{tabular}

${ }^{1}$ Average value, by month; ${ }^{2}$ Maximum value, by month; ${ }^{3}$ Minimum value, by month.

Table 8. The ski slope status-average, maximum and minimum values, by month, during the 2017-2018 winter season.

\begin{tabular}{|c|c|c|c|c|c|c|c|c|}
\hline Status & $\begin{array}{l}\text { Month } \\
\text { Index }\end{array}$ & $\begin{array}{c}\text { November } \\
2017\end{array}$ & $\begin{array}{c}\text { December } \\
2017\end{array}$ & $\begin{array}{c}\text { January } \\
2018\end{array}$ & $\begin{array}{c}\text { February } \\
2018\end{array}$ & $\begin{array}{c}\text { March } \\
2018\end{array}$ & $\begin{array}{c}\text { April } \\
2018\end{array}$ & $\begin{array}{l}\text { Total } \\
\text { Season }\end{array}$ \\
\hline \multirow{3}{*}{$\begin{array}{c}\text { Open } \\
(\%)\end{array}$} & $A v^{1}$ & 5.11 & 23.97 & 53.5 & 68.90 & 51.80 & 11.64 & 44.33 \\
\hline & $\operatorname{Max}^{2}$ & 7.11 & 46.22 & 70.67 & 72.44 & 73.33 & 22.22 & 73.33 \\
\hline & $\operatorname{Min}^{3}$ & 3.11 & 8.00 & 44.44 & 64.89 & 25.33 & 8.00 & 3.11 \\
\hline \multirow{3}{*}{$\begin{array}{c}\text { Open- } \\
\text { Impracticable } \\
(\%)\end{array}$} & $\mathrm{Av}$ & 0.00 & 1.09 & 0.79 & 0.08 & 0.10 & 0.18 & 0.48 \\
\hline & Max & 0.00 & 3.56 & 1.78 & 1.33 & 0.44 & 0.89 & 3.56 \\
\hline & Min & 0.00 & 0.00 & 0.00 & 0.00 & 0.00 & 0.00 & 0.00 \\
\hline \multirow{3}{*}{$\begin{array}{c}\text { Closed } \\
(\%)\end{array}$} & $\mathrm{Av}$ & 94.89 & 74.94 & 45.26 & 31.02 & 48.82 & 88.18 & 55.22 \\
\hline & Max & 96.89 & 91.56 & 54.22 & 35.11 & 74.67 & 92.00 & 96.89 \\
\hline & Min & 92.89 & 53.33 & 29.33 & 27.56 & 26.67 & 77.78 & 26.67 \\
\hline \multirow{3}{*}{$\begin{array}{c}\text { Closed + } \\
\text { Open- } \\
\text { Impracticable }\end{array}$} & $\mathrm{Av}$ & 94.89 & 76.03 & 46.05 & 31.10 & 48.92 & 88.36 & 55.70 \\
\hline & Max & 96.89 & 92.00 & 55.56 & 35.11 & 74.67 & 92.00 & 96.89 \\
\hline & Min & 92.89 & 53.78 & 29.33 & 27.56 & 26.67 & 77.78 & 26.67 \\
\hline
\end{tabular}

${ }^{1}$ Average value, by month; ${ }^{2}$ Maximum value, by month; ${ }^{3}$ Minimum value, by month.

Concerning the 2017-2018 winter season, two points draw particular attention: 18 January 2018 when the percentage of open ski slopes exceeded the threshold of 50\% (52.44\%), 15 March 15 when this percentage fell below $50 \%(46.22 \%)$. It follows that the best period of this season (18 January-14 March) had a duration of only 56 days, which represents $40.58 \%$ days out of the total number of 138 . In addition, we observed that the highest percentage of open slopes (73.33\%) was reached on 4 March 2018 and not in the winter months. In fact, percentages higher than 70\% were registered between 17 February 2018 and 12 March 2018 (24 days); following that, until 17 March 2018, the number of open slopes decreased (remaining opened only $25.33 \%$ of them, which seems to be normal for this period in Romania). Due to the snowfall in the second half of March, the curve became ascending again, with a peak of $44 \%$ on 27 March 2018, following a downward slope until 15 April when the ski season ended (see Figure 1). 


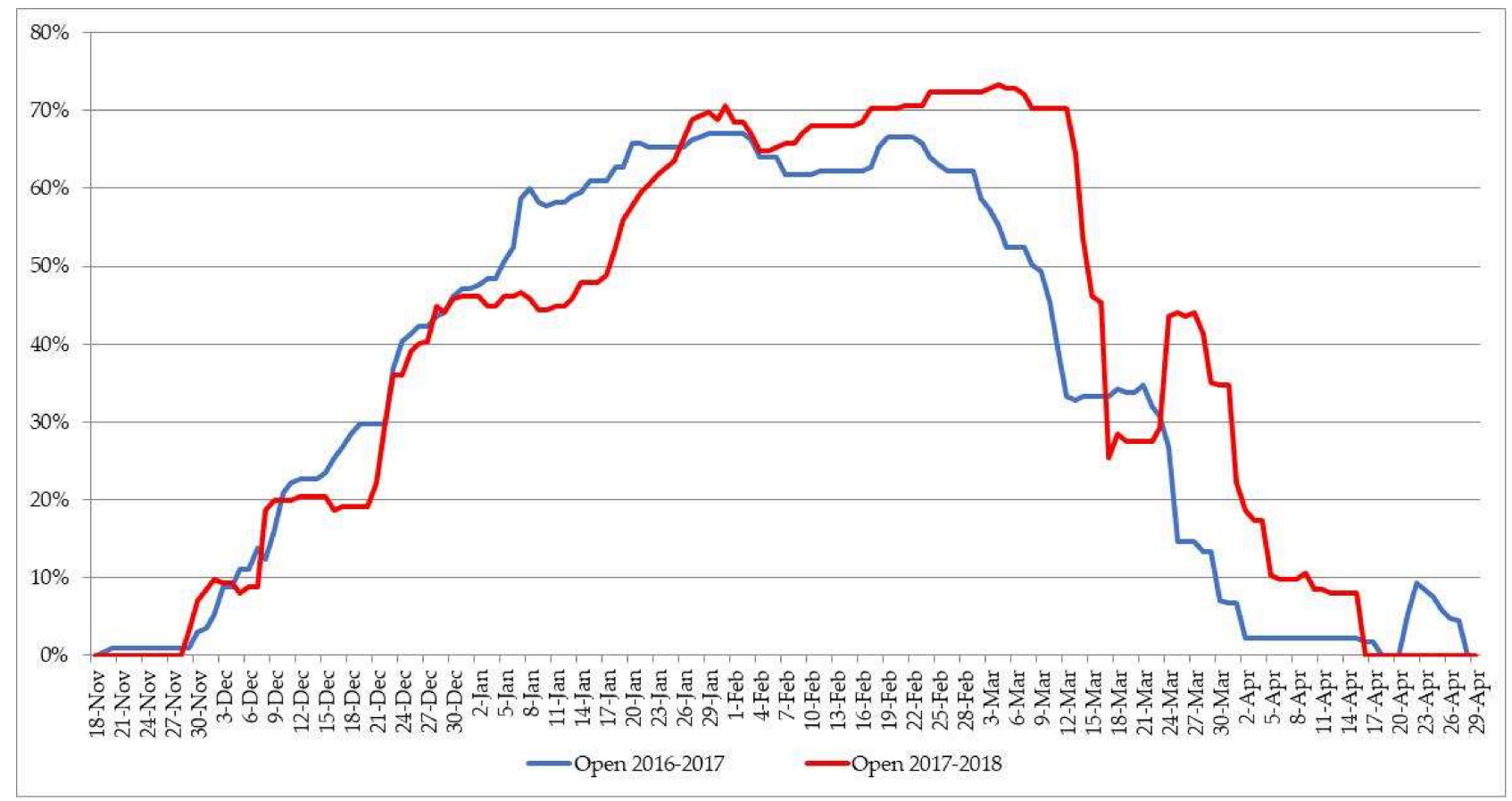

Figure 1. The percentage of open ski slopes during 2016-2017 and 2017-2018 winter seasons.

Although slightly longer in terms of number of days (157 days) the 2016-2017 winter season was not so efficient concerning the functionality of the ski slopes, compared to the previous one. Therefore, in our analysis, we mostly used 2017-2018 winter season.

The length of the season was different in function of ski area location and weather conditions. Taking into consideration only the 175 functional slopes, the operating season covered, on average, 78.6 days, with a minimum of two days and a maximum of 138 days. The average calculated for all the 225 slopes included in the research gave us a value of only 61.1 days.

If we consider the "100-day rule", we can say that only $21.3 \%$ (48 slopes) of 225 slopes complied with this rule, most falling within the range of 50-99 days (43.6\%, 98 slopes), while $35.1 \%$ (79 slopes) were open less than 50 days ( 29 slopes) or were closed (50 slopes).

However, at what altitudes are these ski slopes situated that comply with the 100days rule?

Considering only the 48 ski slopes opened at least 100 days, we observe that $62.5 \%$ of them have a starting altitude at least $1500 \mathrm{~m}$ and none of them below $1000 \mathrm{~m}$. At the same time, $16 \%$ of functional ski slopes have the departure at less than $1000 \mathrm{~m}$ but were open less than 100 days per season (see Table 9).

Table 9. Contingency table: The number of days that ski slopes were open and starting altitude during the 2017-2018 winter season.

\begin{tabular}{|c|c|c|c|c|c|c|c|c|}
\hline \multirow{2}{*}{$\begin{array}{c}\text { Starting } \\
\text { Altitude (m) }\end{array}$} & \multicolumn{8}{|c|}{ Number of Days that Ski Slopes have been Opened } \\
\hline & $1-49$ & $\%$ & $50-99$ & $\%$ & 100-138 & $\%$ & Total & $\%$ \\
\hline$<1000$ & 11 & 37.93 & 17 & 17.35 & 0 & 0.00 & 28 & 16.00 \\
\hline 1000-1199 & 4 & 13.79 & 15 & 15.31 & 7 & 14.58 & 26 & 14.86 \\
\hline $1200-1499$ & 11 & 37.93 & 35 & 35.71 & 11 & 22.92 & 57 & 32.57 \\
\hline 1500-1999 & 2 & 6.90 & 29 & 29.90 & 21 & 43.75 & 52 & 29.71 \\
\hline$\geq 2000$ & 1 & 3.45 & 2 & 2.04 & 9 & 18.75 & 12 & 6.86 \\
\hline Total & 29 & 100.00 & 98 & 100.00 & 48 & 100.00 & 175 & 100.00 \\
\hline
\end{tabular}

The contingency table between the number of days that ski slopes were open and arrival altitude shows us that about $40 \%$ of ski slopes that comply with "100-day rule" 
have the arrival altitude at least $1500 \mathrm{~m}$. Additionally, $60.42 \%$ of the functional ski slopes were open less than 100 days per season and have an arrival altitude less than $1500 \mathrm{~m}$ (see Table 10).

Table 10. Contingency table: The number of days that ski slopes were open and arrival altitude during the 2017-2018 winter season.

\begin{tabular}{ccccccccc}
\hline \multirow{2}{*}{$\begin{array}{c}\text { Arrival } \\
\text { Altitude (m) }\end{array}$} & \multicolumn{7}{c}{ Number of Days the Ski Slopes were Open } \\
\cline { 2 - 9 } & $\mathbf{1 - 4 9}$ & $\mathbf{\%}$ & $\mathbf{5 0 - 9 9}$ & $\mathbf{\%}$ & $\mathbf{1 0 0 - 1 3 8}$ & $\mathbf{\%}$ & Total & \% \\
\hline$<1000$ & 17 & 58.62 & 32 & 32.65 & 7 & 14.58 & 56 & 32.00 \\
$1000-1199$ & 6 & 20.69 & 24 & 24.49 & 11 & 22.92 & 41 & 23.43 \\
$1200-1499$ & 4 & 13.79 & 24 & 24.49 & 11 & 22.92 & 39 & 22.29 \\
$1500-1999$ & 2 & 6.90 & 18 & 18.37 & 19 & 39.58 & 39 & 22.29 \\
\hline Total & 29 & 100.00 & 98 & 100.00 & 48 & 100.00 & 175 & 100.00 \\
\hline
\end{tabular}

Table 11 shows us that $35.42 \%$ of ski slopes, which comply with "100-day rule" are equipped with snow cannons.

Table 11. Contingency table: Snow cannons and the number of days the ski slopes were open during the 2017-2018 winter season.

\begin{tabular}{ccccc}
\hline \multirow{2}{*}{\begin{tabular}{c} 
Number of Days the Ski $\begin{array}{c}\text { Functional Ski Slopes (175) } \\
\text { Slopes were Open }\end{array}$ \\
\cline { 2 - 4 }
\end{tabular}} & & \multicolumn{3}{c}{ Snow Cannons } \\
\cline { 2 - 4 } & & Yes & No & Total \\
\cline { 2 - 4 } & Count & 17.00 & 12.00 & 29 \\
\hline \multirow{2}{*}{$50-99$} & \% of Total & 58.62 & 41.38 & 100 \\
\hline \multirow{2}{*}{$100-138$} & Count & 65.00 & 33.00 & 98 \\
\cline { 2 - 4 } & \% of Total & 66.33 & 33.67 & 100 \\
\cline { 2 - 4 } & Count & 17.00 & 31.00 & 48 \\
\hline Total & \% of Total & 35.42 & 64.58 & 100 \\
\hline & Count & 99.00 & 76.00 & 175 \\
\cline { 2 - 4 } & \% of Total & 56.57 & 43.43 & 100 \\
\hline
\end{tabular}

However, 82 slopes ( $46.86 \%$ of functional ski slopes) with snowmaking facilities fail to be open at least 100 days.

\subsubsection{The Snow Depth and the Ski Slope Conditions}

The data collected for the variable ski slope conditions, presented on the website as an ordinal scale, were associated with snow depth. We calculated the maximum and minimum values for each category of the scale, highlighting several intervals. These values are presented in Table 12, in the following ascending order:

Analyzing the data from Table 12, we notice that the ski slopes were open if the natural snow depth was minimum $15 \mathrm{~cm}$, with the snow cannons adding crop snow if necessary.

The highest snow depth value recorded for each functional ski slope during the season was maintained on average 22.6 days per season. As depicted in Table 13,55.43\% of functional ski slopes have maintained the highest value of snow depth less than 20 days per season, while only $21.71 \%$ of them exceeded 40 days. The maximum was 81 days, while three ski slopes registered only two days. 
Table 12. Minimum and maximum snow depth values during 2017-2018 winter season, according to slope conditions.

\begin{tabular}{ccc}
\hline Ski Slope Conditions & Minimum Value $(\mathbf{c m})$ & Maximum Value $(\mathbf{c m})$ \\
\hline 1. Open-impracticable & 4 & 50 \\
2. Open & 15 & 70 \\
3. Open-difficult conditions & 15 & 25 \\
4. Open-acceptable conditions & 15 & 60 \\
5. Open-good conditions & 18 & 120 \\
6. Open-very good conditions & 30 & 210 \\
7. Open-excellent conditions & 45 & 210 \\
\hline
\end{tabular}

Table 13. Functionality of ski slopes-the number of ski slopes and days with highest snow depth values, during 2017-2018 winter season.

\begin{tabular}{ccc}
\hline Number of Days with Highest Snow Depth & Number of Ski Slopes & \% \\
\hline $1-19$ & 97 & 55.43 \\
$20-39$ & 40 & 22.86 \\
$\geq 40$ & 38 & 21.71 \\
\hline Total & 175 & 100.00 \\
\hline
\end{tabular}

In general, the highest snow depth lasted at least 40 days on a slope characterized by a departure altitude greater or equal than $1500 \mathrm{~m}$. It is the case of $65.78 \%$ of the ski slopes (25 slopes of 38 ). However, the highest percentage (32.57\%) was registered for the slopes situated between $1200 \mathrm{~m}$ and $1499 \mathrm{~m}$ (see Table 14).

Table 14. Contingency table: The number of days with highest snow depth values and starting altitude during 2017-2018 winter season.

\begin{tabular}{ccccccccc}
\hline \multirow{2}{*}{ Starting Altitude (m) } & \multicolumn{7}{c}{ Number of Days with Highest Snow Depth } \\
\cline { 2 - 9 } & $\mathbf{1 - 1 9}$ & $\mathbf{\%}$ & $\mathbf{2 0 - 3 9}$ & $\mathbf{\%}$ & $\mathbf{2 4 0}$ & $\mathbf{\%}$ & Total & $\mathbf{\%}$ \\
\hline$<1000$ & 15 & 15.46 & 10 & 25.00 & 3 & 7.89 & 28 & 16.00 \\
$1000-1199$ & 15 & 15.46 & 6 & 15.00 & 5 & 13.16 & 26 & 14.86 \\
$1200-1499$ & 38 & 39.18 & 14 & 35.00 & 5 & 13.16 & 57 & 32.57 \\
$1500-1999$ & 22 & 22.68 & 8 & 20.00 & 22 & 57.89 & 52 & 29.71 \\
$\geq 2000$ & 7 & 7.22 & 2 & 5.00 & 3 & 7.89 & 12 & 6.86 \\
\hline Total slopes & 97 & 100.00 & 40 & 100.00 & 38 & 100.00 & 175 & 100.00 \\
\hline
\end{tabular}

If we refer to the number of days with highest snow depth and arrival altitude, $39.47 \%$ of the ski slopes with highest snow cover maintained at least 40 days are situated between 1500-1999 m. The highest percentage calculated for functional ski slopes was 32\% and concerned the slopes with arrival altitude less than $1000 \mathrm{~m}$ (see Table 15).

Table 15. Contingency table: The number of days with highest snow depth values and arrival altitude during 2017-2018 winter season.

\begin{tabular}{ccccccccc}
\hline \multirow{2}{*}{ Arrival Altitude (m) } & \multicolumn{7}{c}{ Number of Days with Highest Snow Depth } \\
\cline { 2 - 9 } & $\mathbf{1 - 1 9}$ & $\mathbf{\%}$ & $\mathbf{2 0 - 3 9}$ & $\mathbf{\%}$ & $\mathbf{4} \mathbf{4 0}$ & $\mathbf{\%}$ & Total & $\mathbf{\%}$ \\
\hline$<1000$ & 29 & 29.9 & 17 & 42.5 & 10 & 26.32 & 56 & 32.00 \\
$1000-1199$ & 25 & 25.77 & 11 & 27.5 & 5 & 13.16 & 41 & 23.43 \\
$1200-1499$ & 24 & 24.74 & 7 & 17.5 & 8 & 21.05 & 39 & 22.29 \\
$1500-1999$ & 19 & 19.59 & 5 & 12.5 & 15 & 39.47 & 39 & 22.29 \\
\hline Total slopes & 97 & 100.00 & 40 & 100.00 & 38 & 100.00 & 175 & 100.00 \\
\hline
\end{tabular}


The variable ski slope conditions presented on the website was divided into nine categories, listed at point 3. Concerning the functional ski slopes, from December to April (20172018) the highest percentage corresponded to "acceptable conditions" category, with a pick in February (44.29\% of ski slopes were open in "acceptable conditions"), while in November, during the two days at the beginning of the season, "very good conditions" represented the highest percentage (4.67\%) (see Figure 2$)$.

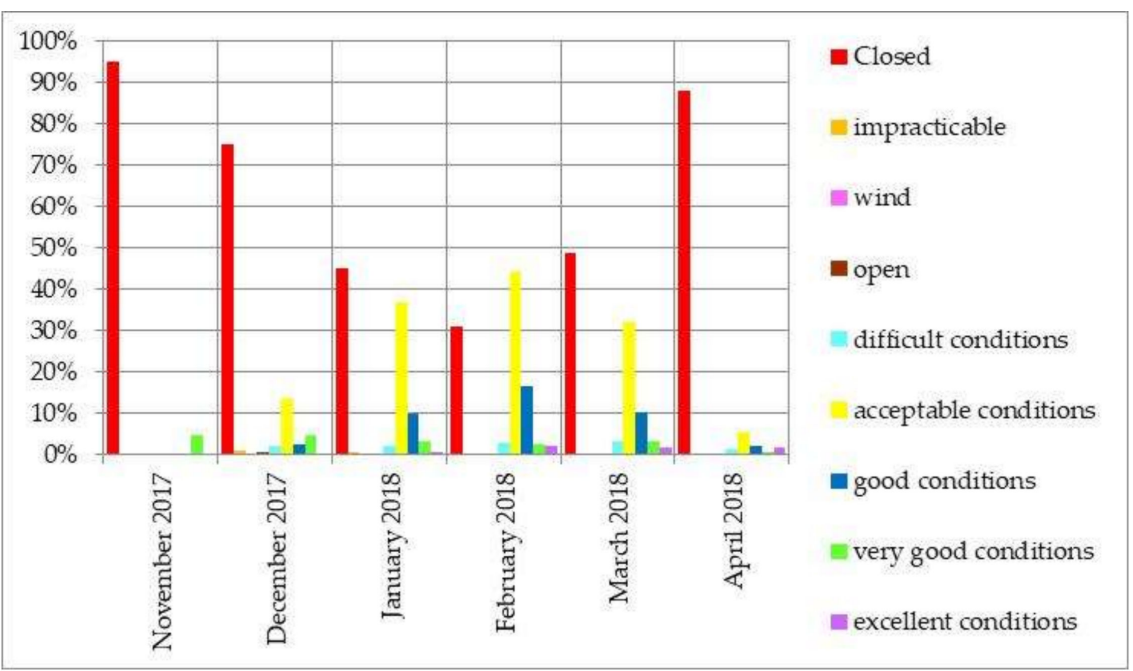

Figure 2. The slope conditions, by month, during 2017-2018 winter season.

The percentages of each category, by month, are shown in Appendix A (see Table 1).

\subsubsection{Efficiency of the Ski Areas}

As is shown in Table 16, 21.74\% ski areas of 69 included in the study have not had at least one open ski slope during the winter season and less than one-quarter $(21.74 \%)$ of them functioned with one or more open ski slopes at least 100 days.

Table 16. Functionality of ski areas: Number of days with at least one open ski slope, during the 2017-2018 winter season.

\begin{tabular}{ccc}
\hline $\begin{array}{c}\text { Number of Days with } \\
\text { at Least one Open Ski Slope }\end{array}$ & Number of Ski Areas & $\%$ \\
\hline 0 & 15 & 21.74 \\
$1-49$ & 11 & 15.94 \\
$50-99$ & 28 & 40.58 \\
$100-138$ & 15 & 21.74 \\
\hline Total ski areas & 69 & 100.00 \\
\hline
\end{tabular}

Analyzing the number of days that a ski area operated at full capacity (all the ski slopes of the ski area were open), we observe that $42.03 \%$ of $69 \mathrm{ski}$ areas have not operated or have had open only a part of ski slopes. If we perform the same calculation, this time taking into account the 54 ski areas where at least one ski slope was open (functional ski areas), we notice that $25.93 \%$ did not operate at full capacity and only $5.56 \%$ have had open all the ski slopes at least 100 days per season (see Table 17). 
Table 17. Functionality of ski areas at maximum capacity during the 2017-2018 winter season.

\begin{tabular}{ccccc}
\hline $\begin{array}{c}\text { Number of Days } \\
\text { at Maximum Capacity }\end{array}$ & $\begin{array}{c}\text { Number } \\
\text { of Ski Areas }\end{array}$ & \% & $\begin{array}{c}\text { Functional } \\
\text { Ski Areas }\end{array}$ & $\%$ \\
\hline 0 & 29 & 42.03 & 14 & 25.93 \\
$1-49$ & 15 & 21.74 & 15 & 27.77 \\
$50-99$ & 22 & 31.88 & 22 & 40.74 \\
$100-138$ & 3 & 4.35 & 3 & 5.56 \\
\hline Total & 69 & 100.00 & 54 & 100.00 \\
\hline
\end{tabular}

Climate change largely affected the ski areas in Romania, with more than a half of them operating at full capacity less than 100 days a year and one-quarter never reached their maximum capacity during the 2017-2018 season, which is not enough to ensure the profitability of the investments.

The elements of presented analysis confirm the first hypothesis. The investments made from the beginning of the ski development policy in Romania are neither questioned nor reoriented under the influence of climate change observable everywhere. The policy put in place actually concerns only the practice of skiing without reorientation in view of the mediocre use of certain infrastructures that are used only a few days a year or not at all. Some ski slopes have been created recently, in the last few years, and have never been used because are located at too low altitude, whereas snow cover problems due to this variable were already well known.

The underuse of existing equipment stems from the lack of natural snow cover that investors are trying to offset by the multiplication of snow cannons in order to create artificial snow (or "snow making") contrary to the international agreement, the Framework Convention on the Protection and Sustainable Development of the Carpathians, presented above. Romania did not comply with none of the three recommendations adopted in this agreement; therefore, the second hypothesis is confirmed.

The capital spent by investors, mostly public money, was unprofitable and the environmental sustainability has been affected. The construction of ski slopes and, even more, ski resorts, has an obvious and significant impact on the environment. Direct impact is because of the cutting of trees in large numbers, the installation of pylons for the lifts-which implies noise and visual nuisances - the creation of artificial water reservoirs for snow cannons, the laying of pipes for these cannons-which requires the use of heavy equipment that compact the fragile soil, etc. Indirect impacts are the creation of roads to bring tourists, the arrival of water, electricity, and the disposal of garbage and wastewater that should be reprocessed hence the creation of treatment plants or waste reprocessing. However, we can fear that this part does not enter into the short-term considerations today in Romania when we know that it took more than 30 years for the French ski resorts to manage to get rid of their waste properly. At the same time, the low level of activity demonstrated cannot lead to a significant economic activity, creating a significant number of jobs. Under these conditions, the sacrifice of the variable "environment" in favor of the variable "economy and employment" is not acceptable.

\section{Limitations of the Study and Future Research}

This research has some limitations concerning the source of data collection. The records concerning the slope conditions and snow depth were collected from a website specialized in snow cover information [37]. These indicators are intended for the ski tourism industry and are provided by qualified persons used to designate the conditions of skiing, the assessment methodology, and the description of these conditions being not specified.

In Romania, there are no official, ministerial, or national nivo-meteorological data targeting each ski slope. The National Meteorological Administration in Romania provides nivological information only from four meteorological stations in the monitored mountain area. If the same study would have been carried out in France and other Western European countries, more reliable data could be used, as there are official bodies, which are method- 
ologically structured. However, it took time to structure the observatories and disseminate their results.

This research concerned only the development of Romanian ski slopes and ski areas. A comparison between several countries will bring new knowledge and a more complex statistical analysis. Furthermore, other ski area characteristics (e.g., number of ski lifts, transport capacity) and climate factors could be considered for future research to highlight new connections between the variables.

\section{Conclusions}

Although Romania is not yet a very important destination to practice winter sports, in the last 10 years, the country has been making major efforts to develop the ski infrastructure in order to attract more visitors, even for a few hours a day.

Since the 2000s, and after a series of studies and projects, it has been decided to modernize and extend the winter sports facilities, mostly for skiing. A first law was adopted in 2003, followed by a series of nearly ten amendments and regulations until today. This incomplete law made the process of modernization and construction of the new ski slopes long and expensive, and the spending of public money and European funds was, in some cases, reckless.

The investments have depended on the resort's classification, national interest, or local interest, the first attracting the most capital. Ascension to power of different political parties, with different visions and objectives, has led to the obstruction of some projects concerning the development of skiing in this country. In addition, a significant number of ski projects were carried out improperly, with ski slopes at too-low altitudes, poorly oriented, and developed with large sums of money spent in vain. The 225 ski slopes studied were open, on average, less than 62 days during the winter season and more than $20 \%$ of them were not even open at all. Only $17.8 \%$ of the slopes complied with the "100-day rule" during the first season included in the study and $21.3 \%$ of them during the second one, which does not ensure profitability. It can be deduced that too many slopes have been created without taking into account the climate change and actual snow conditions. More than a half of ski slopes included in the study were not equipped with snow cannons.

These are negative but also significant examples of a management method, of the use of public money. Although these were initiatives that were officially intended to promote sustainable development, by changing the lives of local communities, by creating economic activity and jobs, the approval and implementation of some of them were the subject of legal investigations.

We may wonder why investments that do not respect any logic of profitability, the environment, or international commitments are made. For those who agree to read between the lines it appears that Romania, like other countries of the former Eastern bloc, is experiencing difficulties in fully becoming a State subject to the rule of law with decision-makers, politicians, and other, concerned with respecting the commitments signed by the State and the use of public funds, national and European.

These results are not due to chance. A series of studies on global warming have been conducted in Romania and in other parts of the world. All of these show that temperature is rising. Even if the study was conducted only for two seasons, we cannot expect an improvement of the existing situation in the future. Solutions exist, but these must be correctly implemented.

Even if the financial and legislative efforts are extended over a long period of time, Romania is trying to develop in this field, increasing its ski area from year to year.

Author Contributions: Conceptualization, S.C. and C.S.; methodology, S.C. and C.S.; formal analysis, S.C.; investigation, S.C.; resources, S.C.; writing-original draft preparation, S.C. and C.S.; writingreview and editing, S.C. and C.S.; visualization, S.C. All authors have read and agreed to the published version of the manuscript.

Funding: This research received no external funding. 
Institutional Review Board Statement: Not applicable.

Informed Consent Statement: Not applicable.

Data Availability Statement: The data presented in this study are available on request from the corresponding author. The data are not publicly available due to their use in future research, which include more variables and comparisons.

Conflicts of Interest: The authors declare no conflict of interest.

\section{Appendix A}

Table 1. Percentages of ski slopes—slope conditions, by month, during 2017-2018 winter season.

\begin{tabular}{|c|c|c|c|c|c|c|c|c|}
\hline Slope Conditions & $\begin{array}{l}\text { Month } \\
\text { Index }\end{array}$ & $\begin{array}{c}\text { November } \\
2017\end{array}$ & $\begin{array}{c}\text { December } \\
2017\end{array}$ & $\begin{array}{c}\text { January } \\
2018\end{array}$ & $\begin{array}{c}\text { February } \\
2018\end{array}$ & $\begin{array}{c}\text { March } \\
2018\end{array}$ & $\begin{array}{c}\text { April } \\
2018\end{array}$ & $\begin{array}{c}\text { Total } \\
\text { Season }\end{array}$ \\
\hline \multirow{3}{*}{ Open (\%) } & Av ${ }^{1}$ & 0.00 & 0.56 & 0.29 & 0.00 & 0.00 & 0.00 & 0.19 \\
\hline & $\operatorname{Max}^{2}$ & 0.00 & 0.89 & 0.89 & 0.00 & 0.00 & 0.00 & 0.89 \\
\hline & $\operatorname{Min}^{3}$ & 0.00 & 0.44 & 0.00 & 0.00 & 0.00 & 0.00 & 0.00 \\
\hline \multirow{3}{*}{$\begin{array}{c}\text { Open- } \\
\text { difficult conditions (\%) }\end{array}$} & Av & 0.44 & 2.18 & 2.38 & 2.83 & 3.20 & 1.36 & 2.47 \\
\hline & Max & 0.44 & 4.44 & 4.44 & 4.00 & 5.33 & 3.11 & 5.33 \\
\hline & Min & 0.44 & 0.44 & 0.89 & 0.89 & 1.33 & 0.00 & 0.00 \\
\hline \multirow{3}{*}{$\begin{array}{c}\text { Open- } \\
\text { acceptable conditions } \\
(\%)\end{array}$} & Av & 0.00 & 13.84 & 37.02 & 44.29 & 32.14 & 5.36 & 28.21 \\
\hline & $\operatorname{Max}$ & 0.00 & 28.00 & 47.56 & 45.78 & 45.33 & 12.89 & 47.56 \\
\hline & Min & 0.00 & 0.89 & 28.44 & 41.78 & 13.78 & 3.56 & 0.00 \\
\hline \multirow{3}{*}{$\begin{array}{c}\text { Open-good } \\
\text { conditions (\%) }\end{array}$} & Av & 0.00 & 2.44 & 9.96 & 16.73 & 10.42 & 2.25 & 8.77 \\
\hline & $\operatorname{Max}$ & 0.00 & 6.22 & 17.78 & 17.33 & 18.67 & 3.56 & 18.67 \\
\hline & Min & 0.00 & 0.00 & 4.44 & 16.00 & 3.56 & 1.78 & 0.00 \\
\hline \multirow{3}{*}{$\begin{array}{c}\text { Open- } \\
\text { very good } \\
\text { conditions (\%) }\end{array}$} & $\mathrm{Av}$ & 4.67 & 4.75 & 3.28 & 2.70 & 3.47 & 0.89 & 3.29 \\
\hline & Max & 6.67 & 8.44 & 7.11 & 4.44 & 6.67 & 2.22 & 8.44 \\
\hline & Min & 2.67 & 1.33 & 0.44 & 1.78 & 0.89 & 0.00 & 0.00 \\
\hline \multirow{3}{*}{$\begin{array}{c}\text { Open- } \\
\text { excellent } \\
\text { conditions (\%) }\end{array}$} & $\mathrm{Av}$ & 0.00 & 0.00 & 0.87 & 2.37 & 1.85 & 1.78 & 1.29 \\
\hline & Max & 0.00 & 0.00 & 2.22 & 2.67 & 2.67 & 1.78 & 2.67 \\
\hline & Min & 0.00 & 0.00 & 0.00 & 2.22 & 0.89 & 1.78 & 0.00 \\
\hline \multirow{3}{*}{ Closed (\%) } & $\mathrm{Av}$ & 94.89 & 74.94 & 45.26 & 31.02 & 48.82 & 88.18 & 55.22 \\
\hline & Max & 96.89 & 91.56 & 54.22 & 35.11 & 74.67 & 92.00 & 96.89 \\
\hline & Min & 92.89 & 53.33 & 29.33 & 27.56 & 26.67 & 77.78 & 26.67 \\
\hline \multirow{3}{*}{$\begin{array}{c}\text { Open- } \\
\text { impracticable (\%) }\end{array}$} & $\mathrm{Av}$ & 0.00 & 1.09 & 0.79 & 0.08 & 0.10 & 0.18 & 0.48 \\
\hline & Max & 0.00 & 3.56 & 1.78 & 1.33 & 0.44 & 0.89 & 3.56 \\
\hline & Min & 0.00 & 0.00 & 0.00 & 0.00 & 0.00 & 0.00 & 0.00 \\
\hline \multirow{3}{*}{ Open-wind (\%) } & $\mathrm{Av}$ & 0.00 & 0.22 & 0.14 & 0.00 & 0.00 & 0.00 & 0.08 \\
\hline & Max & 0.00 & 4.44 & 4.44 & 0.00 & 0.00 & 0.00 & 4.44 \\
\hline & Min & 0.00 & 0.00 & 0.00 & 0.00 & 0.00 & 0.00 & 0.00 \\
\hline
\end{tabular}

${ }^{1}$ Average; ${ }^{2}$ Maximum value; ${ }^{3}$ Minimum value.

\section{References}

1. International Olympic Committee (IOC). IOC and UN Secretariat Agree Historic Deal to Work Together to Use Sport to Build a Better World. Available online: https:/ /www.olympic.org/news/ioc-and-un-secretariat-agree-historic-deal-to-work-togetherto-use-sport-to-build-a-better-world (accessed on 14 September 2019).

2. United Nations General Assembly. Transforming our World: The 2030 Agenda for Sustainable Development. Available online: https://www.un.org/ga/search/view_doc.asp?symbol=A/RES/70/1\&Lang=E (accessed on 9 October 2018).

3. Posea, G. Geomorfologia Romaniei. Relief-Tipuri, Geneza, Evolutie, Regionare, 2nd ed.; Editura Fundatiei Romania de Maine: Bucharest, Romania, 2005; p. 31.

4. Cernaianu, S.; Sobry, C. The development of winter sports tourism in Romania-A historical approach. Eur. J. Tour. Res. 2017, 16, 8-18.

5. David, A. 2012: Radiografia Pârtiilor de Ski Din România. Available online: http://drumliber.ro/2012-radiografia-partiilor-deski-din-romania/ (accessed on 21 May 2020). 
6. Camera Deputatilor. Expunere de Motive la Legea Pentru Aprobarea Programului Naţional de Dezvoltare a Turismului Montan "Super-Schi in Carpati". Available online: http://www.cdep.ro/proiecte/2003/200/80/4/eml_pl284_03.pdf (accessed on 16 January 2019).

7. The Romanian Parliament. Law No 526/2003 to approve The National Program for the development of mountain tourism "Super-ski in the Carpathians". Off. J. Rom. 2003. Part I, No. 901.

8. The Romanian Parliament. Law No 418/2006 concerning the modification and completion of the Law No 526/2003 to approve The National Program for the development of mountain tourism “Ski in Romania". Off. J. Rom. 2006. Part I, No. 961.

9. Ministerul Economiei, Energiei si Mediului de Afaceri. Lista Localitatilor Atestate ca Statiuni Turistice de Interes National, Respectiv Local. Available online: http:/ / turism.gov.ro/web/wp-content/uploads/2020/05/Sta\%C8\%9Biuni-turistice-actualizare13-mai-2020.pdf (accessed on 17 July 2020).

10. The Romanian Government. Government Decision No 122/2002 for the approval of the conditions and the procedure for attesting the tourist resorts, as well as for declaring some localities as tourist resorts of national and respectively local interest. Off. J. Rom. 2002. Part I, No. 770.

11. Tiron, M. La Schi în România: Cele Mai Lungi Zece Pârtii de Schi Din Ţară au o Lungime Totală de 28 de Kilometri, Multe Aşteaptă Să Ningă în Lipsa Tunurilor de Zăpadă. Available online: https:/ / www.zf.ro/companii/la-schi-in-romania-celemai-lungi-zece-partii-de-schi-din-tara-au-o-lungime-totala-de-28-de-kilometri-multe-asteapta-sa-ninga-in-lipsa-tunurilorde-zapada-16039388 (accessed on 12 June 2020).

12. Teodor, M. Aplicații GIS Pentru Proiectarea, Dezvoltarea și Managementul Domeniilor Schiabile din România. Rezumatul Tezei de Doctorat. Bucharest. 2016. Available online: https://www.researchgate.net/publication/327963625_Aplicatii_GIS_pentru_ proiectarea_dezvoltarea_si_managementul_domeniilor_schiabile_din_Romania (accessed on 10 May 2020).

13. Ministerul Economiei, Energiei si Mediului de Afaceri. Partii de Schi Omologate. Available online: http://turism.gov.ro/web/ autorizare-turism/ (accessed on 14 December 2019).

14. Carpathian Convention. Framework Convention on the Protection and Sustainable Development of the Carpathians. Available online: http://www.carpathianconvention.org/tl_files/carpathiancon/Downloads/01\%20The\%20Convention/1.1.1.1_ CarpathianConvention.pdf (accessed on 17 February 2020).

15. World Commission on Environment and Development. Our Common Future; Oxford University Press: Oxford, UK, 1997.

16. Protocol on Sustainable Tourism to the Framework Convention on the Protection and Sustainable Development of the Carpathians. Available online: http:/ / www.carpathianconvention.org/tl_files / carpathiancon/Downloads/01\%20The\%20Convention/ Protocols\%20in\%20pdf/Protocol\%20on\%20Sustainable\%20Tourism_adopted.pdf (accessed on 17 February 2020).

17. Alberton, M.; Andresen, M.; Citadino, F.; Egerer, H.; Fritsch, U.; Götsch, H.; Hoffmann, C.; Klemm, J.; Mitrofanenko, A.; Musco, E.; et al. Outlook on Climate Change Adaptation in the Carpathian Mountains. United Nations Environment Programme, GRIDArendal and Eurac Research, Nairobi, Vienna, Arendal and Bolzano. Available online: http:/ / www.carpathianconvention.org/ tl_files/carpathiancon/Downloads/02\%20Activities/Climate\%20Change/MP_Carpathians_lores.pdf (accessed on 5 May 2020).

18. Scott, D.; Steiger, R.; Rutty, M.; Johnson, P. The future of the Olympic Winter Games in an era of climate change. Curr. Issues Tour. 2015, 18, 913-930. [CrossRef]

19. Goldblatt, D. Playing against the Clock: Global Sport, the Climate Emergency and the Case for Rapid Change. Available online: https://www.rapidtransition.org/resources/playing-against-the-clock/ (accessed on 20 September 2020).

20. Badre, M.; Prime, J.L.; Ribiere, G. Neige de Culture. Etat des Lieux et Impact Environnementaux. Note Socio-Economique. Available online: http:/ / www.farsm.fr/dossiers-externes/neigedeculture.pdf (accessed on 5 December 2019).

21. Beniston, M. Variations of snow depth and duration in the Swiss Alps over the last 50 years: Links to changes in large-scale climatic forcings. Clim. Chang. 1997, 36, 281-300. [CrossRef]

22. Bojariu, R.; Dinu, M. Snow variability and change in Romania. In Proceedings of the Alpine Snow Workshop (2007), Munich, Germany, 5-6 October 2006; pp. 64-68.

23. Micu, D. Snow pack in the Romanian Carpathians under changing climatic conditions. Meteorol. Atmos. Phys. 2009, 105, 1-16. [CrossRef]

24. Administratia Nationala de Meteorologie. Raport anual 2016. Available online: http://www.meteoromania.ro/despre-noi/ raport-anual/raport-anual-2016/ (accessed on 7 December 2020).

25. Witmer, U.; Filliger, R.; Kunz, S.; Kung, R. Erfassung, Bearbeitung und Kartiering von Schneedaten in der Schweiz, Geographica Bernensia G25; Geographisches Institut der Universität Bern: Bern, Switzerland, 1986; ISBN 97839-0629-028-7.

26. Abegg, B.; Agrawala, S.; Crick, F.; Montfalcon, A. Climate change impacts and adaptation on winter tourism. In Climate Change in the European Alps: Adapting Winter Tourism and Natural Hazards Management; Agrawala, S., Ed.; OECD Publishing: Paris, France, 2007; pp. 25-60. ISBN 978-9-2640-3169-2.

27. Marty, C. Climate change and snow cover in the European Alps. In The Impacts of Skiing and Related Winter Recreational Activities on Mountain Environments; Rixen, C., Rolando, A., Eds.; Bentham Science Publishers: Bussum, The Netherlands, 2013 ; pp. 30-44. ISBN 978-1-60805-632-3.

28. Yang, J.; Wan, C. Progress in research on the impacts of global climate change on winter ski tourism. Adv. Clim. Chang. Res. 2010, 1, 55-62. [CrossRef] 
29. Freppaz, M.; Filippa, G.; Corti, G.; Cocco, S.; Williams, M.; Zanini, E. Soil properties on ski runs. In The Impacts of Skiing and Related Winter Recreational Activities on Mountain Environments; Rixen, C., Rolando, A., Eds.; Bentham Science Publishers: Bussum, The Netherlands, 2013; pp. 45-64. ISBN 978-1-60805-632-3.

30. Pintaldi, E.; Hudek, C.; Stanchi, S.; Spiegelberger, T.; Rivella, E.; Freppaz, M. Sustainable soil management in ski areas: Threats and challenges. Sustainability 2017, 9, 2150. [CrossRef]

31. Danciu, F. Pârtia de Schi de 7 Milioane Euro o ia la Vale. Available online: https:/ /www.bistriteanul.ro/partia-de-schi-de-7milioane-euro-o-ia-la-vale/ (accessed on 22 January 2019).

32. Bica, I.; Schuster, E.; Stefanescu, H. Environmental and economic gap-win analysis on the ski area development in the Romanian Carpathians. Case study: Cocos ski slope, Bistrita County. J. Environ. Tour. Anal. 2018, 6, 43-57. [CrossRef]

33. Agerpres. Suceava: Partia de Schi Rarau-Inaugurata la Zece Ani de la Demararea Investitiei, in Prezenta Ministrului Turismului. Available online: https:/ / www.agerpres.ro/administratie/2019/01/05/suceava-partia-de-schi-din-rarau-inaugurata-la-zeceani-de-la-demararea-investitiei-in-prezenta-ministrului-turismului--236197 (accessed on 14 February 2020).

34. Timonea, D. România Lucrului Prost Făcut. Cum s-Au Ras de pe Faţa Pământului 30 de Hectare de Pădure Pentru o Pârtie de Schi Uitată. Adevarul Weekend. Available online: https:/ /adevarul.ro/locale/alba-iulia/romania-lucrului-prost-facut-s-au-rasfata-pamantului-30-hectare-padure-partie-schi-uitata-1_59086fc05ab6550cb8bb11c4/index.html (accessed on 16 February 2019).

35. Andrei, A. Nervi și Dezamăgire pe Pârtia de Schi Din Copou. Teleschiul, Mai Mult Stricat Decât Funcțional. Ziarul de Iasi. Available online: https:/ / www.ziaruldeiasi.ro/stiri/nervi-si-dezamagire-pe-partia-de-schi-din-copou-teleschiul-mai-multstricat-decat-functional--149276.html (accessed on 18 March 2019).

36. Vanat, L. 2019 International Report on Snow and Mountain Tourism. Overview of the Key Industry Figures for Ski Resorts. Available online: https:/ / www.vanat.ch/RM-world-report-2019.pdf (accessed on 20 April 2020).

37. Romania Turistica. Available online: www.romaniaturistica.ro (accessed on 15 April 2018). 